\title{
Peranan Komunikasi Interpersonal Guru dalam Meningkatkan Pengetahuan Anak (Studi pada Guru-guru di PAUD Kharisma dan PAUD Lestari)
}

\author{
Makhmud Zulkifli \\ ${ }^{1}$ Fakultas Ekonomi Universitas Trunojoyo Madura \\ Email: makhmud.zulkifli@trunojoyo.ac.id
}

Naskah diterima 20 Desember 2019, Revisi 15 Januari 2019, Terbit 20 April 2019

\begin{abstract}
Abstrak
DOI: http://dx.doi.org/10.21107/pmt.v12i1.5180

Penelitian ini bertujuan untuk mengetahui bagaimana proses komunikasi yang digunakan guru dalam proses belajar mengajar, bentuk-bentuk komunikasi serta pendekatan-pendekatan komunikasi yang dilakukan guru terhadap anak didik. Penelitian ini menggunakan metode penelitian kualitatif dengan teknik pengumpulan data menggunakan observasi, wawancara mendalam, dan studi dokumen serta teknik analisis data deskriptif dengan presentase. Rumusan masalah penelitian ini adalah bagaimana peranan komunikasi interpersonal guru dalam meningkatkan pengetahuan anak. Berdasarkan hasil penelitian dan pembahasan yang ada, maka yang dapat disimpulkan dalam penelitian adalah sebagai berikut : (1) secara keseluruhan peranan komunikasi interpersonal guru dalam meningkatkan pengetahuan anak disimpulkan cukup baik; (2) bahasa yang digunakan oleh guru sudah sangat tepat dalam berkomunikasi dengan anak didiknya; (3) komunikasi non verbal yang dilakukan guru dalam berinteraksi dengan muridnya adalah dengan menggunakan gerakan, objek tambahan, isyarat, raut dan ekspresi wajah, simbol serta intonasi suara yang bervariasi; (4) pesan yang disampaikan dalam Komunikasi interpersonal guru dengan murid lebih kepada konsep pelajaran dan juga motivasi kepada anak didiknya untuk lebih cepat memahami apa yang dimaksudkan oleh guru tersebut.
\end{abstract}

Kata kunci : bahasa, komunikasi, verbal, guru, balita

\section{PENDAHULUAN}

Permasalahan secara umum adalah seiring hadir banyaknya lembaga pendidikan baik swasta dan negeri tersebut, apakah dibarengi dengan kesiapan tenaga pengajar yang handal dan berkualitas sesuai dengan bidangnya, atau bisa dikatakan, apakah tenaga pengajar (guru) yang ada sesuai dengan kompetensinya. Hal ini yang menjadi pertanyaan tersebut merupakan permasalahan besar terkaitnya dengan perkembangan dunia pendidikan di Indonesia tersebut. Contohnya yang ada di tingkatan taman kanak-kanak atau juga pada tingkatan dibawahnya yaitu Play group. Dari hasil obsevasi awal peneliti dari beberapa sekolah yang ada di Surabaya, adanya data yang menyatakan bahwa seringkali orang tua memindahkan anaknya dari sekolah yang satu ke sekolah yang lain. Setelah diteliti, mendapatkan jawaban bahwa ternyata sekolah yang sebelumnya kualitas gurunya kurang baik, metode pengajaran kurang baik, dan sesuai dengan karakter anak. Beberapa faktor yang menyebabkan kualitas guru kurang baik antara lain tidak terampilnya guru dalam mengajar, kurangnya komunikasi dengan anak didik, guru kurang memahami karakter anak, metode pengajaran yang kurang menarik, kemudian banyaknya anak yang dibiarkan bermain, guru yang tidak sabar dalam mengajar serta berkurangnya jam membaca dan berhitung.

Dari hasil obsevasi atau pengamatan awal peneliti mengenai masalah ini, ternyata bisa dikaitkan dengan kajian bidang ilmu komunikasi, yaitu melihat bagaimana pendekatan komunikasi yang dilakukan oleh guru kepada anak didiknya dalam proses belajar untuk meningkatkan pengetahuan anak tersebut. Oleh sebab itu peneliti sangat tertarik untuk meneliti permasalahan ini pada salah satu sekolah taman kanak-kanak yang memiliki murid yang cukup banyak. Kajian komunikasi yang akan diteliti dalam penelitian ini adalah bagaimana proses komunikasi 
interpersonal yang dilakukan guru dengan anak didik dalam meningkatkan pengetahuan anak sekolah mereka. Lebih khusus pada anak didik taman kanakkanak. Kemampuan seorang guru dalam berkomunikasi harusnya berkualitas, karena berkaitan dengan peningkatan pengetahuan dan juga berkaitan dengan karakter anak sekolah tersebut.

Ada perbedaan pendekatan komunikasi yang dilakukan oleh seorang guru taman kanak-kanak dengan guru pada tingkatan sekolah yang lebih tinggi (SD, SMP, SMA). Salah satu bentuk komunikasi yang harus diperhatikan baikbaik bagi seorang guru taman kanakkanak adalah komunikasi interpersonal. Secara khusus mengenai komunikasi interpersonal menjadi fokus kajian komunikasi pada penelitian ini berkaitan dengan meningkatkan pengetahuan anak sekolah khususnya taman kanak-kanak.

Komunikasi antar pribadi meliputi komunikasi yang terjadi antar pramuniaga dengan pelanggan, anak dengan ayah, dua orang dalam satu wawancara, termasuk antara pengamen jalanan baik dijalanan tempat mereka menjalankan profesinya maupun di tempat-tempat lain (Devito, 1997). Komunikasi antarpribadi melibatkan paling sedikit dua orang yang mempunyai sifat, nilai-nilai pendapat, sikap, pikiran dan perilaku yang khas dan berbeda-beda. Selain itu komunikasi antarpribadi juga menuntut adanya tindakan saling memberi dan menerima diantara pelaku yang terlibat dalam komunikasi. Dengan kata lain, para pelaku komunikasi saling bertukar informasi, pikiran dan gagasan, dan sebagainya.

Komunikasi interpersonal adalah sebuah bentuk khusus dari komunikasi manusia yang terjadi bila kita berinteraksi secara simultan dengan orang lain dan saling mempengaruhi secara mutual satu sama lain, interaksi yang simultan berarti bahwa para pelaku komunikasi mempunyai tindakan yang sama terhadap suatu informasi pada waktu yang sama pula. Pengaruh mutual berarti bahwa para pelaku komunikasi saling terpengaruh akibat adanya interaksi di antara mereka. Interaksi mempengaruhi pemikiran, perasaan dan cara mereka menginterpretasikan sebuah informasi. (Beebe dan Beebe, 1996).

Komunikasi interpersonal pada hakikatnya merupakan salah satu bentuk dari komunikasi pribadi. Komunikasi interpersonal adalah komunikasi antara orang-orang secara tatap muka, yang memungkinkan setiap pesertanya menangkap reaksi orang lain secara langsung, baik secara verbal maupun nonverbal. Sebagai komunikasi yang paling lengkap dan paling sempurna, komunikasi antarpribadi berperan penting hingga kapanpun, selama manusia masih mempunyai emosi. Kenyataannya komunikasi tatap-muka ini membuat manusia merasa lebih akrab dengan sesamanya,berbeda dengan komunikasi lewat media massa seperti surat kabar, televisi, ataupun lewat teknologi tercanggihpun (Mulyana, 2005).

Perspektif interaksi simbolik sebagaimana ditegaskan oleh Mulyana (2005) berusaha memahami perilaku manusia dari sudut pandang subjek dimana perspektif ini menyarankan bahwa perilaku manusia harus dilihat sebagai proses yang memungkinkan manusia membentuk dan mengatur perilakunya dengan mempertimbangkan ekspektasi orang lain yang menjadi mitra interaksi mereka. Bagi Blumer (dalam Mulyana, 2005), interaksiosme simbolik bertumpu pada tiga premis: Pertama, individu merespon suatu situasi simbolik. Mereka merespon lingkungan, termasuk objek fisik (benda) dan objek social (perilaku manusia) makna yang dikandung komponen-komponen lingkungan tersebut bagi mereka. Dengan kata lain, individu dianggap sebagai unsur yang aktif untuk menentukan lingkungan mereka sendiri. Kedua, makna itu berasal dari interaksi sosial seseorang dengan orang lain. Melalui pengunaan simbol, manusia dapa berbagi pengalaman dan pengetahuan tentang dunia. Ketiga, makna itu disempurnakan disaat proses interaksi sosial berlangsung. Jadi, seorang individu juga melakukan proses pemaknaan dalam dirinya sendiri atau disebut sebagai proses pengambilan peran tertutup (covert role-taking). 


\section{METODOLOGI}

Penelitian ini menggunakan metode kualitatif, yaitu suatu penelitian kontekstual yang menjadikan manusia sebagai instrumen, dan disesuaikan dengan situasi yang wajar dalam kaitannya dengan pengumpulan data yang pada umumnya bersifat kualitatif. Menurut Bogdan dan Tylor (1997) dalam Moleong (2000) merupakan prosedur meneliti yang menghasilkan data deskriptif berupa katakata tertulis atau lisan dari orang-orang dan perilaku yang dapat diamati. Pendekatan kualitatif dicirikan oleh tujuan penelitian yang berupaya memahami gejala-gejala yang sedemikian rupa yang tidak memerlukan kuantifikasi, karena gejala tidak memungkinkan untuk diukur secara tepat. Dari hasil penelitian dilapangan tentang komunikasi interpersonal yang dilakukan oleh Guru kepada murid disekolah adalah bentuk komunikasi verbal dan komunikasi non verbal dalam proses proses mengajar untuk meningkatkan pengetahuan anak didik tersebut.

\section{HASIL PEMBAHASAN \\ Komunikasi Verbal oleh Guru dalam Mengajar}

Komunikasi verbal merupakan salah satu bentuk komunikasi yang lazim yang dipergunakan untuk menyampaikan pesan-pesan bisnis kepada pihak lain melalui tulisan maupun lisan. Komunikasi verbal sering dilakukan oleh Guru dalam proses komunikasinya dengan murid disekolah. Komunikasi verbal di anggap sangat efektif dan tepat karena dilakukan langsung bertatap muka dengan murid.

Dari beberapa hasil penelitian melalui wawancara langsung dengan informan penelitian ini tentang komunikasi verbal yang dilakukan guru dalam mengajarkan muridnya dapat ditarik kesimpulan bahwa semua guru yang ada di PAUD Kharisma dan Lestari menggunakan komunikasi dalam bentuk verbal dalam berkomunikasi dan berinteaksi dengan murid-muridnya. Komunikasi verbal dianggap paling tepat dalam berinteraksi dengan murid khususnya anndak Taman kanak-kanak yang kemampuan daya tangkapnya masih rendah dan perlu komunikasi secara langsung.

\section{Komunikasi Non Verbal Guru kepada Muridnya}

Bentuk komunikasi yang kedua yang dilakukan oleh Guru dalam berinteraksi dengan murid-muridnya adalah bentuk komunikasi nonverbal. Komunikasi non verbal adalah komunikasi yang berbaur dengan pembicaraan, misalnya gerakan, ekspresi wajah, gerakan mata, karatristik suara dan penampilan pribadi adalah merupakan suatu bentuk komunikasi nonverbal. Bentuk komunikasi non verbal ini digunakan juga oleh Guru dalam proses berinteraksi dan berkomunikasi dengan anak didiknya di dalam kelas. Komunikasi nonverbal dilakukan dengan tujuan agar murid-murid bisa memahami maksud dari apa yang disampaikan oleh guru kaitannya dengan meningkatkan pengetahuan murid tersebut. Komunikasi nonverbal adalah proses komunikasi dimana pesan disampaikan tidak menggunakan kata-kata.

Para ahli di bidang komunikasi nonverbal biasanya menggunakan definisi "tidak menggunakan kata" dengan ketat, dan tidak menyamakan komunikasi nonverbal dengan komunikasi nonlisan. Contohnya, bahasa isyarat dan tulisan tidak dianggap sebagai komunikasi nonverbal karena menggunakan kata, sedangkan intonasi dan gaya berbicara tergolong sebagai komunikasi nonverbal. Komunikasi nonverbal juga berbeda dengan komunikasi bawah sadar, yang dapat berupa komunikasi verbal ataupun nonverbal. Contoh komunikasi nonverbal ialah menggunakan gerak isyarat, bahasa tubuh, ekspresi wajah dan kontak mata, penggunaan objek seperti pakaian, potongan rambut, dan sebagainya, simbol-simbol, serta cara berbicara seperti intonasi, penekanan, kualitas suara, gaya emosi, dan gaya berbicara.

Dari hasil penelitian didapat bahwa bentuk komunikasi nonverbal juga digunakan oleh Guru dalam proses berinteraksi dengan muridnya. Bentuk komunikasi verbal yang dapat digali oleh peneliti dalam penelitian ini adalah gerak isyarat,bahasa tubuh, ekspresi wajah dan kontak mata, penggunaan objek seperti pakaian, potongan rambut, dan sebagainya, simbol-simbol, serta cara berbicara seperti intonasi, penekanan, 
kualitas suara, gaya emosi, dan gaya berbicara.

Bentuk komunikasi non verbal lainnya juga ditemukan dalam penelitian ini yaitu guru juga menggunakan intonasi suara yang bervariasi dalam berinteraksi dalam kelas dengan murid-murid mereka, dari pernyataan Ibu $\mathrm{Hj}$. Ismiati menyatakan bahwa : "Dalam berkomunikasi dengan murid-murid taman kanak-kanak tersebut kadang-kadang saya harus bersuara dengan keras dan lantang dalam mengajarkan pelajaran kepada mereka, namun juga perlu menggunakan suara yang rendah saja".

Dari hasil penelitian yang menekankan pada bentuk komunikasi non verbal yang dilakukan oleh guru dalam berinteraksi dengan murid-muridnya mendapatkan kesimpulan bahwa guru menggunakan gerakan-gerakan, simbol - simbol, kemudian intonasi suara yang bervariasi, kadang keras dan lembut, kemudian juga bentuk non verbal communication dinyatakan dengan menggunakan objek yang ada di badan seperti baju, celana dan rambut agar supaya murid lebih cepat memahami maksud yang diajarkan oleh guru tersebut. Selain itu juga bentuk komunikasi non verbal yang sering dilakukan oleh guru dalam proses belajar mengajar di kelas adalah menggunakan raut wajah dan kontak mata dalam berinteraksi dengan murid-muridnya.

Pernyataan mengenai penggunaan raut wajah dan ekspresi wajah dalam komunikasi dengan murid dibenarkan oleh Ibu $\mathrm{Hj}$. Ismiati : "Saya selalu menggunakan wajah saya untuk mencontohkan sesuatu kepada anakanak, misalkan saya mengajarkan tentang sedih tentunya saya harus dengan raut wajah yang sedih, agar anak-anak bisa langsung mengerti maksud saya".

Kesemuanya itu merupakan bentuk komunikasi non verbal yang digunakan oleh guru dalam berkomunikasi dengan muridnya yang ditemukan pada hasil penelitian ini dan tentunya bertujuan untuk meningkatkan pengetahuan anak-anak tersebut. Komunikasi non verbal sangat tepat digunakan oleh guru karena mengingat daya tangkap anak taman kanak-kanak masih belum cepat oleh sebab itu perlu dilakukan verbal komunikasi seperti yang telah di bahas pada hasil penelitian di atas.

\section{Isi Pesan (message) oleh Guru kepada Murid}

Berbicara proses komunikasi tentunya tidak terlepas pada pesan atau message yang disampaikan, diatas tadi telah di sampaikan dan dijelaskan secara rinci hasil penelelitian tentang proses komunikasi dari unsur komunikator dan bahasa yang digunakan, berikut ini adalah pesan, yang berarti membahas tentang isi dari pesan tersebut yang disampaikan oleh komunikator, dalam hal ini adalah Guru PAUD Kharisma dan Lestari, atau secara jelas lagi isi pesan yang disampaikan oleh guru kepada muridnya dalam proses belajar mengajar tersebut.

Penuturan dari Ibu Endah yang juga selaku kepala sekolah di PAUD Kharisma dan Lestari tentang isi pesan yang disampaikan guru kepada murid adalah pada umumnya lebih cenderung pada materi pelajaran.

Begitu juga dari hasil pernyataan guru lainnya, isi pesan yang disampaikan tentunya adalah tentang pelajaran, namun ketika peneliti menggali secara mendalam tentang isi pesan yang disampaikan guru kepada murid kaitannya dengan meningkatkan pengetahuan anak didik mereka, mendapatkan beberapa hasil yang cukup variatif berikut beberapa pernyataan informan : Ibu Endah "kalau isi pesan yang mengerakkan murid untuk belajar tentunya kami guru-guru selalu memberikan motivasi kepada mereka antara lain mengatakan kepada anakanak agar giat belajar agar supaya cepat naik kelas". Kemudian lbu saya memberikan motivasi kepada mereka dalam setiap kali "saya mengajarkan materi pelajaran, adalah dengan memberikan hadiah kepada anak-anak apabila cepat memahami materi tersebut, misalkan memberikan pujian, atau kesempatan pulang lebih dahulu dari teman-teman murid yang lain."

Pernyataan yang beda ketika menanyakan mengenai isi pesan yang disampaikan guru kepada murid kaitannya dengan meningkatkan pengetahuan mereka ditemukan pada informan berikut 
ini : pernyataan wawancara dengan lbu Endah: "Saya kalau mengajar agar supaya murid cepat mengerti saya memberikan motovasi berupa ganjaran apabila ada yang tidak cepat mengikuti apa yang saya ajarkan, tujuannya adalah dengan adanya ganjaran yang saya sampaikan tersebut akan memotivasi anak-anak untuk lebih konsentrasi dalam belajar"

Dari hasil penelitian dapat disimpulkan bahwa pesan dalam proses komunikasi yang disampaikan oleh guru kepada murid dalam kaitannya dengan meningkatkan pengetahuan anak didik tersebut lebih khusus di PAUD Kharisma dan Lestari adalah dominan pada materi pelajaran dan motivasi belajar anak-anak.

Pesan yang berkualitas akan membantu tercapainya tujuan komunikasi yaitu kesepahaman makna, dalam penelitian ini pesan guru yang berkualitas yang berisikan pelajaran kepada muridnya akan cepat dimengerti oleh muridnya apabila gurunya memberikan pesan yang tepat dalam berkomunikasi. Ketepatan menggunakan media, saluran ataupun konsep pesan tersebut akan tergantung juga pada kualitas sumber daya guru tersebut. Faktor ini akan mempengaruhi peningkatan pengetahuan anak didik tersebut.

Pada dasarnya komunikasi intra-pribadi adalah manusia selalu berinteraksi dengan sesama manusia tentunya dengan menggunakan komunikasi. Salah satu jenis komunikasi adalah komunikasi antar pribadi (interpersonal communication). Komunikasi interpersonal (antar-pribadi) yang dilakukan Guru adalah pada saat dia berinteraksi dengan muridnya dikelas. Komunikasi interpersonal menunjuk kepada komunikasi dengan orang lain. Komunikasi jenis ini dibagi lagi menjadi komunikasi diadik, komunikasi publik, dan komunikasi kelompok-kecil.

Model Jendela Johari memusatkan pada keseimbangan komunikasi interpersonal. Komunikasi interpersonal termasuk : pidato, komunikasi nonverbal, penyimpulan, parafrase. Memiliki kemampuan komunikasi inter-personal yang baik mendukung proses-proses seperti: perdagangan, konseling, pelatihan, bimbingan, pemecahan konflik.
Seperti yang diketahui komunikasi interpersonal adalah komunikasi yang berlangsung diantara dua orang yang mempunyai hubungan yang mantap dan jelas. Komunikasi antar-pribadi juga menuntut adanya tindakan saling memberi dan menerima diantara pelaku yang terlibat dalam komunikasi. Komunikasi inter-personal merupakan subyek dari beberapa disiplin dalam bidang psikologi, terutama analisis transaksional. Komunikasi ini dapat dihalangi oleh gangguan komunikasi atau oleh kesombongan, sifat malu dan lain-lain.

Komunikasi yang dilakukan oleh guru PAUD Kharisma dan Lestari adalah dengan berbicara langsung didepan kelas ataupun dengan pribadi masing-masing murid tersebut. Kesimpulannya bahwa semua guru yang ada di PAUD Kharisma dan Lestari menggunakan komunikasi dalam bentuk verbal dalam berkomunikasi dan berinteaksi dengan murid-muridnya. Komunikasi verbal dianggap paling tepat dalam berinteraksi dengan murid khususnya anndak Taman kanak-kanak yang kemampuan daya tangkapnya masih rendah dan perlu komunikasi secara langsung.

Bentuk komunikasi yang lain yang dilakukan oleh Guru dalam berinteraksi dengan murid-muridnya adalah bentuk komunikasi nonverbal. Komunikasi non verbal adalah komunikasi yang berbaur dengan pembicaraan, misalnya gerakan, ekspresi wajah, gerakan mata, karatristik suara dan penampilan pribadi adalah merupakan suatu bentuk komunikasi nonverbal. Bentuk komunikasi non verbal ini digunakan juga oleh Guru dalam proses berinteraksi dan berkomunikasi dengan anak didiknya di dalam kelas. Komunikasi nonverbal dilakukan dengan tujuan agar murid-murid bisa memahami maksud dari apa yang disampaikan oleh guru kaitannya dengan meningkatkan pengetahuan murid tersebut. Komunikasi nonverbal adalah proses komunikasi dimana pesan disampaikan tidak menggunakan kata-kata.

Bentuk komunikasi non verbal lainnya juga ditemukan dalam penelitian ini yaitu guru juga menggunakan intonasi suara yang bervariasi dalam berinteraksi dalam kelas dengan murid-murid mereka 
Penggunaan bahasa daerah ini lebih sering digunakan oleh Guru apabila melakukan komunikasi interpersonal atau dalam situasi tatap muka dengan tujuan untuk mempermudah proses penyampaian pesan kepada muridnya berkaitan dengan pelajaran dikelas karena akan lebih cepat dimengerti dan direspons lebih baik ketimbang penggunaan bahasa yang tidak dipahami oleh murid. Teknis penggunaan bahasa daerah ini disesuaikan dengan kondisi audiense yang ada dilapangan.

Hasil penelelitian tentang proses komunikasi dari unsur komunikator dan bahasa yang digunakan, berikut ini adalah pesan, yang berarti membahas tentang isi dari pesan tersebut yang disampaikan oleh komunikator, dalam hal ini adalah Guru PAUD Kharisma dan Lestari, atau secara jelas lagi isi pesan yang disampaikan oleh guru kepada muridnya dalam proses belajar mengajar tersebut.

Isi pesan yang disampaikan guru kepada murid adalah pada umumnya lebih cenderung pada materi pelajaran.

\section{KESIMPULAN}

Dari hasil yang dibahas sebelumnya dapatkan ditarik kesimpulan penelitian ini bahwa :

1. Peranan komunikasi interpersonal guru dalam meningkatkan pengetahuan anak sudah cukup baik karena menggunakan komunikasi secara verbal dan non verbal berinteraksi dengan murid sekolah taman kanakkanak.

2. Bahasa yang digunakan oleh guru sudah sangat tepat dalam berkomunikasi dengan anak didiknya yaitu bahasa Indonesia sebagai bahasa baku disekolah dan juga disertai bahasa atau dialeg daerah manado, untuk membantu pemahaman anak didiknya tentang materi pelajaran.

3. Komunikasi non verbal yang dilakukan guru dalam berinteraksi dengan muridnya adalah dengan menggunakan gerakan, objek tambahan, isyarat, raut dan ekspresi wajah, simbol serta intonasi suara yang bervariasi.

4. Pesan yang disampaikan dalam Komunikasi interpersonal guru dengan murid lebih kepada konsep pelajaran dan juga motivasi kepada anak didiknya untuk lebih cepat memahami apa yang dimaksudkan oleh guru tersebut.

\section{DAFTAR PUSTAKA}

Beebe,S.A., Beebe,S.J \& Redmond, M.V. 1999. Interpersonal CommunicationRelating to Others (2nd ed). USA: Allyn and Bacon.

Creswell, J.W. 1994. Qualitative Inquiry and Reasearch Design. Sage. California.

Devito, J.A. 1997. Komunikasi Antar Manusia: Kuliah Dasar. Edisi kelima, Diterjemahkan oleh Agus Maulana. Professional Books. Jakarta.

Fuchan, A. 1992. Pengantar Metode Penelitian Kualitatif. Penerbit Djambatan. Jakarta.

Littlejohn. J.S. 1999. Theories of Human Communication. Belmont. California: Wadsworth Publishing Company.

Liliweri, A. 1991. Komunikasi Antar Pribadi. Citra Aditya Bhakti. Bandung.

Moleong, L.J. 2007. Metodologi Penelitian Kualitatif. Remaja Rosda Karya. Bandung.

Mulyana, D. 2002. IImu Komunikasi: Suatu Pengantar.Remaja Rosdakarya. Bandung:

Sadiman, A. 1986. Media Pendidikan, Pendidikan, Pengembangan dan Pemanfaatannya. Grafindo. Jakarta. 
2 Jurnal Pamator 